\title{
Screening of Burkholderia spp. from oil palm plantation with antagonistic properties against Ganoderma boninense
}

\author{
YURNALIZA YURNALIZA ${ }^{1, \bullet}$, DITA ISNAINI RAMBE ${ }^{1}$, LISTRA SARIMUNGGU ${ }^{1}$, MEYLISA PURBA ${ }^{1}$, \\ ISNAINI NURWAHYUNI ${ }^{1}$, SOVIA LENNY ${ }^{2}$, ANISA LUTFIA ${ }^{1}$, ADRIAN HARTANTO ${ }^{1}$ \\ ${ }^{1}$ Department of Biology, Faculty of Mathematics and Natural Sciences, Universitas Sumatera Utara, J1. Bioteknologi No. 1, Medan 20155, \\ North Sumatra, Indonesia. Tel./fax.: +62-81362447554, `email: yurnaliza@usu.ac.id \\ ${ }^{2}$ Department of Chemistry, Faculty of Mathematics and Natural Sciences, Universitas Sumatera Utara, Jl. Bioteknologi No. 1, Medan 20155, \\ North Sumatra, Indonesia.
}

Manuscript received: 14 June 2020. Revision accepted: 2 July 2020.

\begin{abstract}
Yurnaliza. Rambe DI, Sarimunggu L, Purba M, Nurwahyuni I, Lenny S, Lutfia A, Hartanto A. 2020. Screening of Burkholderia spp. from oil palm plantation with antagonistic properties against Ganoderma boninense. Biodiversitas 21: $3431-3437$. Burkholderia spp. are ubiquitous diazotrophic bacteria within $\beta$-Proteobacteria group, known for its occurrence in variety of niches from aquatic to terrestrial habitats and as endophytes. Beneficial strains of Burkholderia have been reported as plant growth-promoting rhizobacteria or as antagonistic bacteria against phytopathogenic fungi. This study evaluated the potential of multiple strains of Burkholderia spp. recovered from three ecological niches, such as rhizosphere, humus soil, and root endophytes of oil palm plantations in North Sumatra to suppress the growth of basal stem rot causative agent in oil palm (Elaeis guineensis Jacq.) by Ganoderma boninense Pat. The antagonistic isolates were identified on the basis of molecular identification using 16S rDNA sequence (27F1462R), revealing twelve isolates (48\%) as members of Burkholderia cepacia complex (Bcc), with other minor genera, such as Chitinophaga, Klebsiella, Mycobacterium, Paenibacillus, Rhizobium, Serratia, Stenotrophomonas, and Xanthomonas. The antagonistic activities as expressed in the percentage inhibition of radial growth (PIRG) against G. boninense were considerably potential with the highest percentage of 55\%. In comparison, the crude extract (MeOH, EtOAc) was also tested against G. boninense colonies showing PIRG from 0 to $38 \%$. Majority of isolates did not show any visible chitinolytic activity based on plate assay, in exception to $B$. contaminans $\mathrm{RC} 02$ while most of them were producers of glucanase. The collection of indigenous Burkholderia spp. originating from North Sumatran oil palm plantations, i.e. B. cepacia, B. contaminans, B. metallica, and B. stagnalis may then be considered as potential biocontrol agents against $G$. boninense based on their antagonistic activities, antifungal properties, and hydrolytic enzyme activities.
\end{abstract}

Keywords: 16S rDNA, Basal stem rot, Burkholderia contaminans, Elaeis guineensis, Ganoderma boninense

\section{INTRODUCTION}

Oil palm (Elaeis guineensis Jacq.) is a valuable tropical crop with intensive productivity in countries of Southeast region, such as Indonesia and Malaysia. Collectively, Indonesia and Malaysia produce $84 \%$ of the global palm oil with progressive trend in each year (Ommelna et al. 2012). In Indonesia, the center of oil palm plantation is located in Sumatra Island which supported the national income from the palm oil industries. Hence, the island has been proposed as a model in studying the success of oil palm growing sites in SE region with the prospect of development and manufacture of a variety of downstream products (Paterson and Lima 2017; Paterson 2019). Despite its growing popularity as a tropical oil, many challenges have been identified, from the issue of deforestation and conversion of natural sites which impact on the biodiversity, to the on-going onset of diseases such as basal stem rot (BSR) and upper stem rot (UPR) caused by the basidiomycetous fungus, Ganoderma boninense Pat. Regarding the diseases, it has been documented since 80 years ago and still considered as serious diseases in Indonesia (Corley and Tinker 2016).
Ganoderma boninense is categorized as the most challenging disease-causing agent which caused direct loss to the palm oil yields by infecting the bottom part of the stem leading to decay and disruption of nutrient uptake by the plant. If the diseases progress, the older fronds wilt and form a skirt around the trunk, while the plants have been considered dead under this condition (Hushiarian et al. 2013). The required step then is to promote early replanting for replacing the unproductive oil palms in the growing sites (Flood et al. 2005). Strategies in managing the disease onset have been promoted by various efforts, from early detection of infected seedlings, to direct or indirect control of the pathogenic fungus. Chemical control by injecting some fungicides to the oil palm, for example, hexaconazole and dazomet incorporated in chitosan nanoparticle were reported to effectively control the fungus growth (Maluin et al. 2019). However, the presence of dissipated and leached chemicals into the environment may pose a threat to both terrestrial and aquatic life as toxic compounds while recent development is still needed to ensure the environmental issue of the fungicides application (Maznah et al. 2015). 
An alternative way to control the growth of $G$. boninense is by introducing biological control agents to diseased oil palms. This may be approached with preventive and curative methods through inoculation and application of antagonistic microorganisms capable of inhibiting the growth of $G$. boninense during certain periods of planting. A wide range of antagonistic bacteria, both from gram-positive and gram-negative genera such as Bacillus, Burkholderia, Enterobacter, and Pseudomonas, have been reported to not only inhibit the colony growth of $G$. boninense in the laboratory studies but also success in the field trials (Bivi et al. 2010; Suryanto et al. 2012; Buana et al. 2014; Irma et al. 2018). The application of bacteria as biocontrol agents is promising due to its adaptive traits in less favorable environments following the induction of systemic resistance (ISR) to the plants (Ferreira et al. 2007).

Burkholderia is a genus of diazotrophic bacteria commonly present as soil inhabitants with two different lineages either as opportunistic organismal pathogens or as beneficial microbes with plant growth-promoting traits and biocontrol potential (Compant et al. 2006). Members of Burkholderia have also been reported for their antifungalproducing ability to control the phytopathogenic fungus, Ganoderma boninense. Endophytic Burkholderia cepacia GanoEB2 inhibits the growth of $G$. boninense and displayed a reduction of disease incidence in 6-month oil palm seedlings planted in Malaysia (Ramli et al. 2016). Endophytic Burkholderia sp. B212 displayed the highest inhibition to the colony of $G$. boninense compared to other Burkholderia strains originating from rhizosphere region (Buana et al. 2014). Indigenous Burkholderia strains may be explored and studied progressively to identify the prominent isolates in suppressing the growth of $G$. boninense for future field application (Muniroh et al. 2019). To date, there is still limited information on the indigenous Burkholderia strains originating from the North Sumatra region. The present study reports the occurrence and diversity of Burkholderia spp. as the dominant bacteria group isolated from rhizosphere and humus soil in oil palm plantations with antagonistic properties against $G$. boninense.

\section{MATERIALS AND METHODS}

\section{Study sites and collection of samples}

Three oil palm plantation sites located in Medan city, North Sumatra were chosen in this study. Site I, was the oil palm plantation managed by Universitas Sumatera Utara; Site II, was the oil palm plantation managed by one of the local state-owned enterprises or PT. Perkebunan Nusantara IV (PTPN IV); and Site III, was the oil palm plantation managed by one of the local communities. Three ecological niches were designated as isolation sources for Burkholderia spp., such as rhizosphere, humus soil, and plant internal tissue or root endophyte. Rhizospheric soils, humus soils, and root samples of Elaeis guineensis were sampled adequately, stored in sterile zip-lock bags, and transported to the laboratory for further processing.

\section{Isolation of Burkholderia}

A nitrogen-deficient medium or Ashby's Mannitol Agar (AMA) medium for diazotrophic bacteria was used to isolate naturally-occurring Burkholderia strains with medium composition of (g/L): mannitol $(20 \mathrm{~g}), \mathrm{KH}_{2} \mathrm{PO}_{4}$ $(0.2 \mathrm{~g}), \mathrm{MgSO}_{4}(0.2 \mathrm{~g}), \mathrm{NaCl}(0.2 \mathrm{~g}), \mathrm{K}_{2} \mathrm{SO}_{4}(0.1 \mathrm{~g})$, $\mathrm{CaCO}_{3}(5 \mathrm{~g})$, and agar $(15 \mathrm{~g})$. Approximately $10 \mathrm{~g}$ of rhizospheric and humus soils were suspended in $90 \mathrm{~mL}$ distilled water and made into serial dilutions. An aliquot of $0.1 \mathrm{~mL}$ from each dilution was spread on top of AMA medium and incubated at $28{ }^{\circ} \mathrm{C}$ for $7 \mathrm{~d}$. In addition, isolation of root endophytes was based on Yurnaliza et al. (2014) by surface-sterilizing the root fragments into following desinfectants such as $75 \% \mathrm{EtOH}$ ( $2 \mathrm{~min}$ ), 5.3\% $\mathrm{NaOCl}$ (5 min), 75\% EtOH (30 s), and sterile distilled water $(1 \mathrm{~min})$. The dried root fragments were then placed on top of AMA medium and incubated at $28{ }^{\circ} \mathrm{C}$ for $7 \mathrm{~d}$. Any growing bacterial colonies were purified and preserved in fresh AMA medium until further use.

\section{DNA amplification and 16S rDNA sequencing}

The bacterial isolates were extracted for its genomic DNA following the protocol of Wizard® Genomic DNA Purification Kit (United States) based on the principle of DNA extraction by Doyle and Doyle (1987). DNA amplification in the region of $16 \mathrm{~S}$ rDNA used a universal primer for bacterial identification (Weisburg et al. 1991), the 27F (5'-AGAGTTTGATCMTGGCTCAG-3') and 1492R (5'-GGTTACCTTGTTACGACTT-3') primers with a PCR reaction containing $8.5 \mu \mathrm{L}$ nuclease-free water (NFW), $12.5 \mu \mathrm{L} 2 \times$ GoTaq DNA Polymerase, $1 \mu \mathrm{L}$ of each primer, $2 \mu \mathrm{L}$ DNA template with a total volume of $25 \mu \mathrm{L}$. The PCR was programmed in a thermal cycler for reaction specifications such as: $94{ }^{\circ} \mathrm{C}(2 \mathrm{~min}), 92{ }^{\circ} \mathrm{C}(30 \mathrm{sec}), 55{ }^{\circ} \mathrm{C}$ (30 sec), $72{ }^{\circ} \mathrm{C}(1 \mathrm{~min})$, and $72{ }^{\circ} \mathrm{C}(5 \mathrm{~min})$, with total of 40 cycles. Visible DNA amplicons with good quality from agarose gel electrophoresis were sent to Macrogen, Inc. (Singapore) for $16 \mathrm{~S}$ rDNA sequencing.

\section{Phylogenetic tree construction}

Raw 16S rDNA consensus sequences from each isolate were subjected to BLASTn searches by selecting the optimized database for Archaea or Bacteria in the targeted loci information project (Altschul et al. 1990). The retrieved BLAST sequences were aligned using MUSCLE and constructed into a phylogenetic tree using a characterbased method or maximum likelihood following the best DNA substitution model (Hasegawa-Kishino-Yano) featured in MEGA $X$ software with a bootstrapping of 1000 replications (Hasegawa et al. 1985; Kumar et al. 2018).

\section{Antagonistic test between Ganoderma boninense and Burkholderia isolates.}

The phytopathogenic fungus, Ganoderma boninense was obtained from the fungal collection of Indonesian Oil Palm Research Institute (IOPRI), Medan, Indonesia, previously grown on fresh Potato Dextrose Agar (PDA) medium. The antagonistic test was based on dual culture method by measuring the percentage inhibition of radial 
growth (PIRG) of $G$. boninense colony against Burkholderia isolates (Bivi et al. 2010). The G. boninense mycelial plug was placed 3 days priorly at the center of PDA medium while the Burkholderia isolates were inoculated on the four-edge against $G$. boninense colony using inoculation loop. The medium was incubated at $28{ }^{\circ} \mathrm{C}$ for $5 \mathrm{~d}$. All experiments were conducted in triplicates.

\section{Extraction of bioactive metabolites and antifungal test}

Production of antifungal metabolites by Burkholderia isolates was performed in both liquid-state and solid-state fermentation. For liquid-state fermentation, bacterial isolates were previously grown into Nutrient Broth (NB) and incubated at $28{ }^{\circ} \mathrm{C}$ under $100 \mathrm{rpm}$ agitation for $5 \mathrm{~d}$. Solvent, EtOAc was added into the liquid medium (v/v, 1: 1) to extract the fungal metabolites by macerating it rigorously for $3 \mathrm{~d}$. The top layer of solution was decanted and concentrated in vacuo to obtain crude extracts. For solid-state fermentation, bacterial isolates were fully streaked on Nutrient Agar (NA) medium and incubated at $28{ }^{\circ} \mathrm{C}$ for $5 \mathrm{~d}$. The agar medium was cut into smaller fragments and immersed into $250-\mathrm{mL}$ flask containing 40 $\mathrm{mL} \mathrm{MeOH}$ in sufficient volume following rigorous maceration for $3 \mathrm{~d}$. The solution was filtered and concentrated in vacuo to obtain crude extracts. Both extracts were dissolved into $10 \%$ (v/v) DMSO in sterile distilled water. Similar to antagonistic test, the colony of $G$. boninense was placed 3 days priorly at the center of PDA medium while the antifungal extracts were inoculated 50 $\mu \mathrm{L}$ into sterile paper disk and placed on the four-edge against $G$. boninense colony. The medium was incubated at $28{ }^{\circ} \mathrm{C}$ for $5 \mathrm{~d}$. All experiments were conducted in triplicates.

\section{Detection of extracellular chitinase and glucanase using plate assays}

Extracellular chitinase and glucanase produced by Burkholderia isolates were visually detected using plate assays. Chitinase was detected using colloidal chitin agar composed of $(\mathrm{g} / \mathrm{L})$ in sterile distilled water: $0.7 \mathrm{~g} \mathrm{~K}_{2} \mathrm{HPO}_{4}$, $0.3 \mathrm{~g} \mathrm{KH}_{2} \mathrm{PO}_{4}, 0.5 \mathrm{~g} \mathrm{MgSO}_{4} .7 \mathrm{H}_{2} 0,0.01$ g FeSO $4.7 \mathrm{H}_{2} \mathrm{O}$, $0.001 \mathrm{~g} \mathrm{ZnSO}_{4}, 0.001 \mathrm{~g} \mathrm{MnCl}_{2}$, colloidal chitin (2 g), and bacto agar (15 g) (Yurnaliza et al. 2017). Clear zones around bacterial colonies indicate a positive result of chitinase activity. Glucanase was detected using glucan agar composed of $(\mathrm{g} / \mathrm{L})$ : laminarin $(10 \mathrm{~g})$, agarose $(8 \mathrm{~g})$ in $0.1 \mathrm{M}$ sodium acetate buffer $(\mathrm{pH} 5.0)$. Clear zones around bacterial colonies after flooding the plate with $1 \%$ congo red $(5 \mathrm{~min})$ and $1 \mathrm{M} \mathrm{NaCl}$ indicate a positive result of glucanase activity (Michalko et al. 2013). All detectable hydrolytic zones were measured in indexes with respect to the colony growth of each isolate.

\section{RESULTS AND DISCUSSION}

Identification of Burkholderia species and other genera

Twenty-five diazotrophic bacterial isolates were successfully recovered from three different niches in oil palm plantation using AMA medium. Twelve isolates (48\%) were identified as species in Burkholderia based on $16 \mathrm{~S}$ rDNA sequencing and BLASTn search results (data not shown). In addition, we also isolated other genera of gram-positive and negative bacteria such as Chitinophaga (2 isolates), Klebsiella (1 isolate), Mycobacterium (1 isolate), Paenibacillus (2 isolates), Rhizobium (3 isolates), Serratia (2 isolates), Stenotrophomonas (1 isolate), and Xanthomonas (1 isolate), which have also been reported to display nitrogen fixation abilities. There are different community assemblages from each niche which indicated specific preferences of bacterial species towards different environmental conditions (Figure 1). Members of Burkholderia were mostly isolated as soil inhabitants, both from rhizospheric and humus soil in oil palm plantations. There were no culturable Burkholderia species as root endophyte in our study.

The isolation medium was commonly used to isolate Azotobacter spp., however majority of Burkholderia spp. were also reported as plant-associated nitrogen fixers with diverse habitat across geographical origins (Santos et al. 2001). Burkholderia vietnamensis was regarded as the first $\mathrm{N}_{2}$-fixing species among its relatives, which was isolated from the rhizosphere of rice plants (Gillis et al. 1995). Due to the increasing studies of naturally occurring Burkholderia, many species have been isolated as diazotrophic bacteria with prospect as plant growth promoting rhizobacteria. This study then supports the use of AMA in possibility of obtaining Burkholderia isolates from natural environments. The finding of none Burkholderia endophytic isolates may reveal that the soil environment was more favorable to the free-living lifestyle than being endophytes for the growth and enumeration of population in natural state. Specific factor in determining the community structure and diversity of soil Burkholderia community was the low soil acidity $(\mathrm{pH})$ which was also a common feature in oil palm plantations (Von-Uexkull and Mutert 1995; Stopnisek et al. 2014).

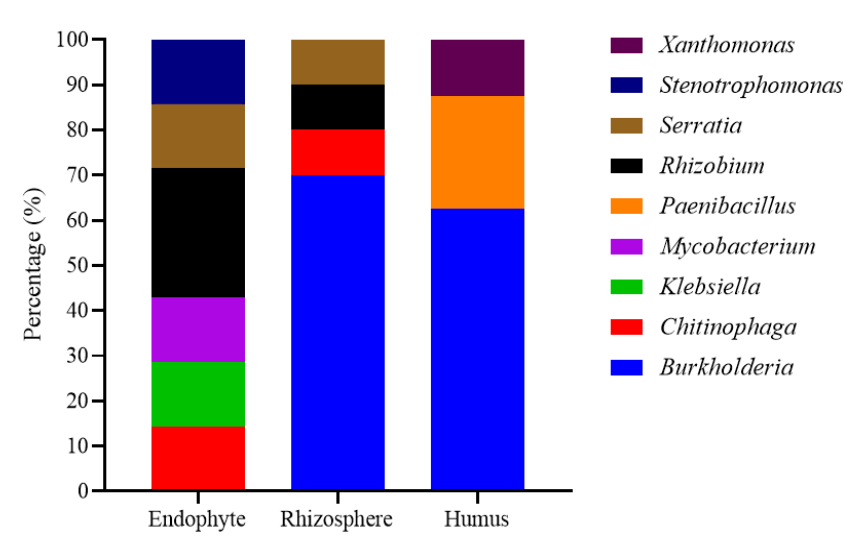

Figure 1. Community composition (\%) of Burkholderia species and other bacteria genera isolated from three different niches in oil palm plantation 
Phylogenetic relationship among Burkholderia isolates and GenBank database

We constructed a phylogenetic tree to illustrate the relationships among Burkholderia isolates based on the similarity of $16 \mathrm{~S}$ rDNA sequences with database sequences available in GenBank. Although BLASTn resulted in high scores of identification, it may not reflect the accurate genetic relationship based on sequence alignment analysis (Koski and Golding 2001). The use of targeted loci project database was considered as valid due to the deposit of type specimens for species check and evaluation. The phylogenetic tree was then constructed using a maximum likelihood statistical method to analyze each character or nucleotides involved in evolutionary means (Figure 2). Based on the species delimitation, we identified our isolates as Burkholderia cepacia (1 isolate), $B$. contaminans (8 isolates), B. metallica (2 isolates), and $B$. stagnalis (1 isolate). All 16S rDNA sequences of each isolate have been deposited into GenBank database to obtain accession numbers (MT_565298-MT_565309).

Burkholderia contaminans is the dominant species inhabiting the soil environment of oil palm plantations in our study, followed by $B$. metallica as the second dominant and the least B. cepacia and B. stagnalis. All species belonged to the members of Burkholderia cepacia complex (Bcc), a group of bacteria that were considered as opportunistic pathogen but possessed beneficial biological traits for agricultural applications and biodegradation purposes (Mahenthiralingam et al. 2008). The species can be found in a wide array of environmental gradient exclusively in low pH soils. Historically, B. stagnalis was the newest described novel species in 2015, followed by the description of $B$. contaminans in 2009, B. metallica in 2008, and the oldest B. cepacia in 1949 (Vanlaere et al. 2008; Vanlaere et al. 2009; Smet et al. 2015). To our most understanding, the occurrence of $B$. contaminans and $B$. stagnalis in oil palm plantations may be considered as new reports for the information of other isolation sources of Burkholderia species.

\section{Antagonistic and antifungal activity of Burkholderia isolates}

Dual culture method was used to screen a large population of antagonistic Burkholderia isolates by inhibiting the colony growth of $G$. boninense, as expressed in PIRG (\%). In general, the antagonistic test gave a higher result in PIRG $(55 \%)$ to compared to the antifungal activities from metabolite extracts produced by Burkholderia in batch fermentation (38\%) (Table 1; Figures 3 and 4). A variety of antagonistic level was observed among isolates in which the strongest antagonist was displayed by $B$. contaminans HA09 with PIRG of $55.5 \%$, followed with B. contaminans HA01 (51.1\%), and $B$. contaminans $\mathrm{RC} 02$ (47.3\%). Antifungal activity of $\mathrm{MeOH}$ extracts showed that $B$. metallica RA01 produced the highest activity with PIRG of $38.1 \%$, followed with $B$. contaminans HA01 (36\%), and both for B. cepacia HB21 and $B$. contaminans RB02 (31.6\%). Antifungal activity of EtOAc extracts showed that B. metallica RA01 produced the highest activity with PIRG of $27.2 \%$, followed with $B$. contaminans $\mathrm{RC} 03$ (26.6\%), and B. contaminans RC02 (20\%). In contrast, some $\mathrm{MeOH}$ extracts displayed no antifungal activities compared to EtOAc although the results were higher in general.

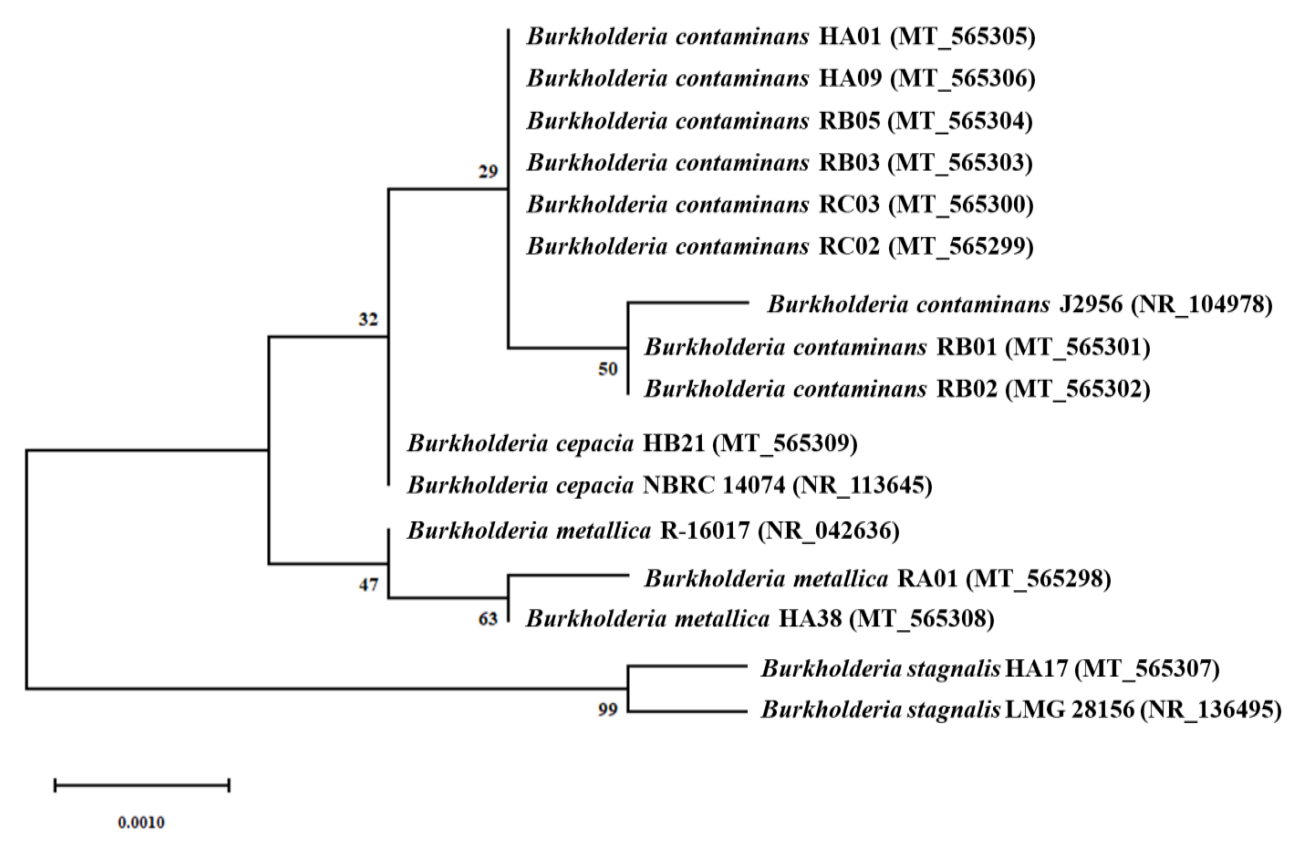

Figure 2. Phylogenetic tree of 16S rDNA sequences of the twelve isolated Burkholderia species using the maximum likelihood (ML) method with 1,000 bootstrap replications. The tree was constructed using MEGA X. 


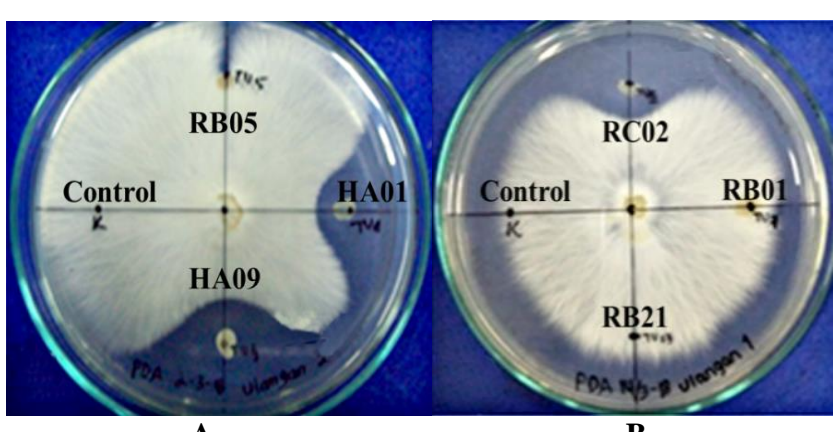

A

B

Figure 3. Antagonistic test results of representative Burkholderia isolates against $G$. boninense colony after incubation at $28{ }^{\circ} \mathrm{C}$ for $5 \mathrm{~d}$ in PDA medium

Table 1. Antagonistic and antifungal activities of Burkholderia isolates against $G$. boninense colony as expressed in the percentage inhibition of radial growth (PIRG)

\begin{tabular}{lccc}
\hline \multirow{2}{*}{ Isolate } & \multicolumn{3}{c}{ PIRG (\%) } \\
\cline { 2 - 4 } & $\begin{array}{c}\text { Anta- } \\
\text { gonism }\end{array}$ & MeOH & EtOAc \\
\hline Burkholderia cepacia HB21 & 31.4 & 31.6 & 6.6 \\
Burkholderia contaminans HA01 & 51.1 & 36.0 & 7.1 \\
Burkholderia contaminans HA09 & 55.5 & - & 5.3 \\
Burkholderia contaminans RB01 & - & 24.0 & 15.8 \\
Burkholderia contaminans RB02 & 31.4 & 31.6 & 6.6 \\
Burkholderia contaminans RB03 & 34.2 & 10.5 & 13.3 \\
Burkholderia contaminans RB05 & - & 28.8 & 10.5 \\
Burkholderia contaminans RC02 & 47.3 & 21.1 & 20.0 \\
Burkholderia contaminans RC03 & 36.8 & 5.2 & 26.6 \\
Burkholderia metallica HA38 & 46.6 & - & 9.5 \\
Burkholderia metallica RA01 & 44.4 & 38.1 & 27.2 \\
Burkholderia stagnalis HA17 & - & 14.3 & 5.0 \\
\hline
\end{tabular}

Both Burkholderia contaminans and B. metallica showed prominent and promising antagonistic activities against $G$. boninense, although $B$. contaminans displayed a higher activity based on antagonistic test collectively. The higher result in antagonistic tests may be explained by the spatial and nutrient competition in dual culture plate which later induced the Burkholderia strains to synthesize more versatile antifungal metabolites and hydrolytic enzymes to inhibit the growth of their competitors for the resources (Mille-Lindblom et al. 2006). Moreover, Burkholderia contaminans have been reported to synthesize various antifungal metabolites that were controlled by genetic regulatory elements ( $\mathrm{Gu}$ et al. 2009). Oligopeptide produced by $B$. contaminans strain MS14 was reported to inhibit the colony growth of Geotrichum candidum, a human invasive pathogenic fungal species whereas the mutants with silenced gene in the region of AmbR1 produced an $80 \%$ decrease of antifungal activities when tested against the pathogenic fungus ( $\mathrm{Gu}$ et al. 2009). In another study, it was revealed that $B$. contaminans strain MS14 also produced occidiofungin, a unique glycopeptide antifungal compound which was secreted during

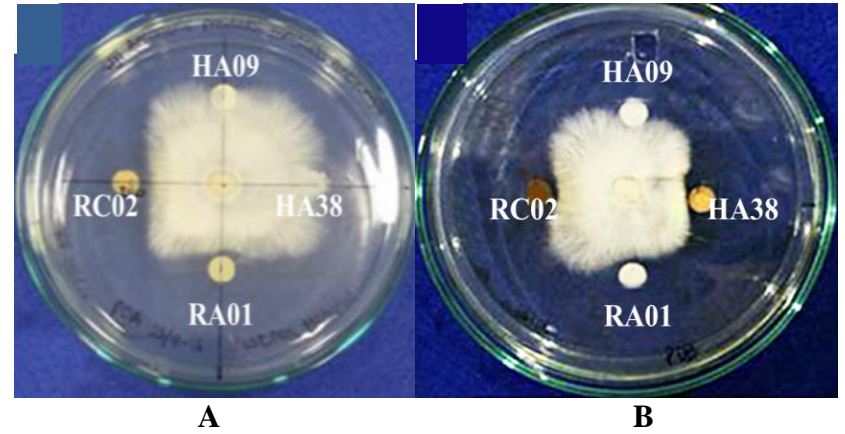

Figure 4. Antifungal test results of representative Burkholderia extracts against $G$. boninense colony after incubation at $28{ }^{\circ} \mathrm{C}$ for $5 \mathrm{~d}$ in PDA medium. A: $\mathrm{MeOH}$ extracts; B: EtOAc extracts.

Table 2. Chitinolytic and glucanolytic index of Burkholderia isolates in plate assay

\begin{tabular}{lcc}
\hline \multirow{2}{*}{ Isolate } & \multicolumn{2}{c}{ Hydrolytic Index } \\
\cline { 2 - 3 } & Chitinase & Glucanase \\
\hline Burkholderia cepacia HB21 & - & 2.5 \\
Burkholderia contaminans HA01 & - & 0.5 \\
Burkholderia contaminans HA09 & - & 1.7 \\
Burkholderia contaminans RB01 & - & 3.1 \\
Burkholderia contaminans RB02 & - & 2.6 \\
Burkholderia contaminans RB03 & - & - \\
Burkholderia contaminans RB05 & - & 2.3 \\
Burkholderia contaminans RC02 & 2.7 & 2.6 \\
Burkholderia contaminans RC03 & - & 3.1 \\
Burkholderia metallica HA38 & - & 1.5 \\
Burkholderia metallica RA01 & - & 2.4 \\
Burkholderia stagnalis HA17 & - & 0.6 \\
\hline
\end{tabular}

fermentation in liquid culture with biocontrol potential against lawn disease ( $\mathrm{Lu}$ et al. 2009). The plant-growthpromoting strain of $B$. contaminans has also been reported through the utilization of $B$. contaminans strain KNU17BI1 isolated from maize rhizospheric soil to effectively control the onset of diseases like banded leaf and sheath blight of maize caused by Rhizoctonia solani (Tagele et al. 2018). The strain also displayed a broad spectrum of antagonistic activities against genera of phytopathogenic fungi such as Alternaria, Colletotrichum, Fusarium, Pythium, and Stemphylium based on laboratory test. In contrary, little is still known regarding the bioprospection study of $B$. metallica which may be further explored and exploited in the field of biological application.

\section{Chitinolytic and glucanolytic activities from Burkholderia isolates}

The ability to produce extracellular hydrolytic enzymes such as chitinase and glucanase may also explain the mechanisms in controlling the growth of $G$. boninense during its hyphal formation as most filamentous fungi cell walls are composed of chitin and $\beta$-1,3-glucan (Latge 
2007). Chitinase acts as a hydrolytic enzyme in converting the polymeric chitin substrate into $\mathrm{N}$-acetylglucosamine (NAG) monomers while glucanase acts on substrates with glycosidic type of glucans to be converted into monomeric sugars. Based on the plate assays, majority of Burkholderia strains were more capable of producing glucanase than chitinase as expressed in hydrolytic index (Table 2). Only B. contaminans $\mathrm{RC} 02$ was able to hydrolyze the chitin substrate as carbon source for their growth as indicated from the clear zones around colonies. Meanwhile, the highest glucanolytic index was displayed by both $B$. contaminans $\mathrm{RB} 01$ and $B$. contaminans $\mathrm{RC} 03$ with an index of 3.1, followed with B. contaminans RB02 (2.6), $B$. contaminans $\mathrm{RC} 02$ (2.6), and B. cepacia $\mathrm{HB} 21$ (2.5). Only $B$. contaminans RB03 which did not display any glucanolytic zone around its colony. The varying degree in hydrolytic activities showed that each strain was different in terms of physiological traits.

Chitinase and glucanase are key enzymes to enhance the antifungal activity of secondary metabolites produced by Burkholderia species. Chitinase produced by some members of Burkholderia was considered as unique due to its similarity with Streptomyces gene family, yet revealed its additional feature in disease suppression by $G$. boninense (Kong et al. 2001). Glucanase was also reported to be produced by an Indonesian strain of $B$. cepacia BiogenCC E76 isolated from rice plants with antifungal activity against Colletotrichum gloeosporioides (Manzila et al. 2015). Moreover, chitinase, glucanase, peroxidase (POX), and phenylalanine ammonia-lyase (PAL) are examples of pathogenesis-related proteins (PRPs) commonly involved in host defense mechanism by oil palm (Sahebi et al. 2018). Another approach is to introduce the harmless or endophytic strains of Burkholderia into root environment to induce systemic resistance in oil palm through increased genetic expression of PRPs to combat the G. boninense infection (Hushiarian et al. 2013). Previous trial has shown that the inoculation of fungal endophytes into oil palm root environment increased the chitinase activity by oil palm after 1 week of post-treatment (WPT) (Yurnaliza et al. 2017). This strategy may then be applied after significant results in field trials by using our indigenous Burkholderia strains in future studies. The results of our study then add the collection of indigenous Burkholderia species of Indonesia, especially $B$. contaminans and B. metallica which were still limited of their information.

\section{ACKNOWLEDGEMENTS}

This research was fully funded by the Ministry of Research, Technology and Higher Education of the Republic of Indonesia with research grant No. 48/UN5.2.3.1/PPM/KP-DRPM/2018. The authors would also express the highest gratitude to the Integrated Laboratory (Laboratorium Terpadu) and Laboratory of Microbiology, Faculty of Mathematics and Natural Sciences, Universitas Sumatera Utara for facilitating this project.

\section{REFERENCES}

Altschul SF, Gish W, Miller W, Myers EW, Lipman DJ. 1990. Basic local alignment search tool. J Mol Biol 215 (3): 403-410.

Bivi MR, Farhana MSN, Khairulmazmi A, Idris A. 2010. Control of Ganoderma boninense: a causal agent of basal stem rot disease in oil palm with endophyte bacteria in vitro. Intl J Agr Biol 12 (6): 833-839.

Buana RFN, Wahyudi AT, Toruan-Mathius N. 2014. Control activity of potential antifungal-producing Burkholderia sp. in suppressing Ganoderma boninense growth in oil palm. Asian J Agric Res 8 (5): 259-268.

Compant S, Nowak J, Coenye T, Clement C, Barka EA. 2006. Diversity and occurrence of Burkholderia spp. in the natural environment. FEMS Microbiol Rev 32 (4): 607-626.

Corley RHV, Tinker PB. 2016. The Oil Palm. Wiley Blackwell: USA.

Doyle JJ, Doyle JL. 1987. A rapid DNA isolation procedure for small quantities of fresh leaf tissue. Phytochem Bull 19: 11-15.

Ferreira RB, Monteiro S, Freitas R, Santos CN, Chen Z, Batista LM, Duarte J, Borges A, Teixeira AR. 2007. The role of protein defence proteins in fungal pathogenesis. Mol Plant Pathol 8: 677-700.

Flood J, Keenan L, Wayne S, Hasan Y. 2005. Studies on oil palm trunks as sources of infection in the field. Mycopathologia 159 (1): 101-107.

Gillis M, Tran VV, Bardin R, Goor M, Hebbar P, Willems A, Segers P, Kersters K, Heulin T, Fernandez MP. 1995. Polyphasic taxonomy in the genus Burkholderia leading to an amended description of the genus and proposition of Burkholderia vietnamiensis sp. nov. for N2fixing isolates from rice in Vietnam. Intl J Syst Bacteriol 45 (2): 274289.

Gu G, Wang N, Chaney N, Smith L, Lu SE. 2009. AmbR1 is a key transcriptional regulator for production of antifungal activity of Burkholderia contaminans strain MS14. FEMS Microbiol Lett 297 (1): 54-60.

Gu G, Smith L, Wang N, Wang H, Lu SE. 2009. Biosynthesis of antifungal oligopeptide in Burkholderia contaminans strain MS14. Biochem Biophys Res Commun 380 (2): 328-332.

Hasegawa M, Kishino H, Yano T. 1985. Dating the human-ape split by a molecular dock of mitochondrial DNA. J Mol Evol 22: 160-174.

Hushiarian R, Yusof NA, Dutse SW. 2013. Detection and control of Ganoderma boninense: strategies and perspectives. SpringerPlus 2: 555. DOI: 10.1186/2193-1801-2-555

Irma A, Meryandini A, Rupaedah B. 2018. Biofungicide producing bacteria: an in vitro inhibitor of Ganoderma boninense. Hayati J Bio Sci 25 (4): 151-159.

Kumar S, Stetcher G, Li M, Knyaz C, Tamura K. 2018. MEGA X: Molecular Evolutionary Genetics Analysis across computing platforms. Mol Biol Evol 35 (6): 1547-1549.

Kong H, Shimosaka M, Ando Y, Nishiyama K, Fujii T, Miyashita K, 2001. Species-specific distribution of a modular family 19 chitinase gene in Burkholderia gladioli. FEMS Microbiol Ecol 37: 135-141.

Koski LB, Golding GB. 2001. The closest BLAST hit is often not the nearest neighbor. J Mol Evol 52: 540-542.

Latge JP. 2007. The cell wall: a carbohydrate armour of the fungal cell. Mol Microbiol 66: 279-290.

Lu SE, Novak J, Austin FW, Gu G, Ellis D, Kirk M, Stanford SW, Tonelli M, Smith L. 2009. Occidiofungin, a unique antifungal glycopeptide produced by a strain of Burkholderia contaminans. Biochemistry 48 : 8312-8321.

Mahenthiralingam E, Baldwin A, Dowson CG. 2008. Burkholderia cepacia complex bacteria: opportunistic pathogen with important natural biology. J Appl Microbiol 104: 1539-1551.

Maluin FN, Hussein MZ, Yusof NA, Fakurazi S, Seman IA, Hilmi NHZ, Daim LDJ. 2019. Enhanced fungicidal efficacy on Ganoderma boninense by simultaneous co-delivery of hexaconazole and dazomet from their chitosan nanoparticles. RSC Adv 9: 27083-27095.

Manzila I, Priyatno TP, Fathin MF, Ambarsari L, Suryadi Y, Sanudra IM, Susilowati DN. 2015. Karakterisasi $\beta-1,3-1,4$-glukanase bakteri endofitik Burkholderia cepacia isolat E76 asal tanaman padi. Berita Biologi 14: 143-153.

Maznah Z, Halimah M, Ismail S, Idris AS. 2015. Dissipation of the fungicide hexaconazole in oil palm plantation. Environ Sci Pollut Res Intl 22: 19648-19657.

Michalko J, Socha P, Mesrazos P, Blehova A, Libantova J, Moravcikova J, Matusikova I. 2013. Glucan-rich diet is digested and taken up by the carnivorous sundew (Drosera rotundifolia L.): implication for a novel role of plant $\beta$-1,3-glucanases. Planta 238: 715-725. 
Mille-Lindblom C, Fischer H, Tranvik LJ. 2006. Antagonism between bacteria and fungi: substrate competition and a possible tradeoff between fungal growth and tolerance towards bacteria. Oikos 113: 233-242.

Muniroh MS, Nusaibah SA, Vadamalai, G, Siddique Y. 2019. Proficiency of biocontrol agents as plant growth promoters and hydrolytic enzyme producers in Ganoderma boninense infected oil palm seedlings. Curr Plant Biol 20: 100116. DOI: 10.1016/j.cpb.2019.100116

Ommelna BG, Jennifer AN, Chong KP. The potential of chitosan in suppressing Ganoderma boninense infection in oil-palm seedlings. J Sustain Sci Manage 7: 186-192.

Paterson RRM, Lima N. 2017. Climate change affecting oil palm agronomy, and oil palm cultivation increasing climate change, require amelioration. Ecol Evol 8: 452-461.

Paterson RRM. 2019. Ganoderma boninense disease of oil palm to significantly reduce production after 2050 in Sumatra if projected climate change occurs. Microorganisms 7: 24 DOI: $10.3390 /$ microorganisms7010024

Ramli NR, Mohamed MS, Seman IA, Zairun MA, Mohamad N. 2016 The potential of endophytic bacteria as a biological control agent for Ganoderma disease in oil palm. Sains Malaysiana 45: 401-409.

Sahebi M, Hanafi MM, Mohidin H, Rafii MY, Azizi P, Idris AS, Fariz A, Abiri R, Taheri S, Moradpoor M. 2018. Antioxidant enzyme activities and secondary metabolite profiling of oil palm seedlings treated with combination of NPK fertilizers infected with Ganoderma boninense. Biomed Res Intl 2018: 1494157. DOI: 10.1155/2018/1494157

Santos PEDL, Bustillos-Cristales R, Caballero-Mellado J. 2001 Burkholderia, a genus rich in plant-associated nitrogen fixers with wide environmental and geographic distribution. Appl Environ Microbiol 67: 2790-2798.

Smet BD, Mayo M, Peeters C, Zlosnik JEA, Spilker T, Hird TJ, LiPuma JJ, Kidd TJ, Kaestli M, Ginther JL, Wagner DM, Keim P, Bell SC, Jacobs JA, Currie BK, Vandamme P. 2015. Burkholderia stagnalis sp. nov. and Burkholderia territorii sp. nov., two novel Burkholderia cepacia complex species from environmental and human sources. Int J Syst Evol Microbiol 65: 2265-2271.
Stopnisek N, Bodenhausen N, Frey B, Fierer N, Eberl L, Weisskopf L. 2014. Genus-wide acid tolerance accounts for the biogeographical distribution of soil Burkholderia populations. Environ Microbiol 16: 1503-1512.

Suryanto D, Wibowo RH, Siregar EBM, Munir E. 2012. A possibility of chitinolytic bacteria utilization to control basal stem diseases caused by Ganoderma boninense in oil palm seedling. Afr J Microbiol Res 6: 2053-2059.

Tagele SB, Kim SW, Lee HG, Kim HS, Lee YS. 2018. Effectiveness of multi-trait Burkholderia contaminans KNU17BI1 in growth promotion and management of banded leaf and sheath blight in maize seedling. Microbiol Res 214: 8-18.

Vanlaere E, LiPuma JJ, Baldwin A, Henry D, Brandt ED, Mahenthiralingam E, Speert D, Dowson C, Vandamme P. 2008. Burkholderia latens sp. nov., Burkholderia diffusa sp. nov., Burkholderia arboris sp. nov., Burkholderia seminalis sp. nov., and Burkholderia metallica sp. nov., novel species within the Burkholderia cepacia complex. Intl J Syst Evol Microbiol 58: 15801590 .

Vanlaere E, Baldwin A, Gevers D, Henry D, Brandt ED, LiPuma JJ, Mahenthiralingam E, Speert DP, Dowson C, Vandamme P. 2009. Taxon K, complex within the Burkholderia cepacia complex, comprises at least two novel species, Burkholderia contaminans sp. nov. and Burkholderia lata sp. nov. Intl J Syst Evol Microbiol 59: 102-111.

Von-Uexkull HR, Mutert E. 1995. Global extent, development and economic impact of acid soils. Plant Soil 171: 1-15. DOI: $10.1007 / \mathrm{BF} 00009558$

Weisburg WG, Barns SM, Pelletier DA, Jane DJ. 1991. 16S ribosomal DNA amplification for phylogenetic study. J Bacteriol 173: 697-703.

Yurnaliza Y, Aryantha INP, Esyanti RR, Susanto A. 2014. Antagonistic activity assessment of fungal endophytes from oil palm tissues against Ganoderma boninense Pat. Plant Pathol J 13 (4): 257-267.

Yurnaliza, Esyanti RR, Susanto A, Aryantha INP. 2017. The chitinase activity of oil palm (Elaeis guineensis Jacq.) roots against fungal endophytes and pathogenic Ganoderma boninense. Plant Omics J 10: 247-251. 